Article

\title{
A Conceptual Model for Green Human Resource Management: Indicators, Differential Pathways, and Multiple Pro-Environmental Outcomes
}

\author{
Engin Ari ${ }^{1, * \mathbb{C}}$, Osman M. Karatepe $\left.{ }^{1} \mathbb{(}\right)$, Hamed Rezapouraghdam ${ }^{2}$ and Turgay Avci ${ }^{1}$ \\ 1 Faculty of Tourism, Eastern Mediterranean University, Gazimagusa TRNC 99628, Turkey; \\ osman.karatepe@emu.edu.tr (O.M.K.); turgay.avci@emu.edu.tr (T.A.) \\ 2 School of Tourism and Hotel Management, Bahçeşehir Cyprus University, Mustafa Kemal Avenue, \\ Osmanlar St. No.1, Alayköy, Lefkosa TRNC 99200, Turkey; hamed.aqdam@cyprus.bau.edu.tr \\ * Correspondence: engin.ari@emu.edu.tr
}

Received: 12 July 2020; Accepted: 28 August 2020; Published: 31 August 2020

\begin{abstract}
There is a growing awareness of green human resource management (GHRM) in the environmental sustainability research in hospitality and tourism literature. The extant literature also delineates review studies about GHRM. Despite the existence of these studies, there is still a paucity of research about a parsimonious model that includes the underlying mechanisms linking GHRM to multiple pro-environmental behaviors. In view of such a gap, using the ability-motivation-opportunity framework, social exchange theory, social information processing and reformulation of attitude theories, and the happy-productive thesis as the theoretical underpinnings, our study proposes a conceptual model of GHRM. Specifically, our study links GHRM to organizationally valued pro-environmental behaviors such as task-related pro-environmental behaviors, proactive pro-environmental behaviors, green recovery performance, and green voice behavior through the mediating roles of work engagement and job satisfaction. In addition, our search of the relevant literature highlights eight indicators of GHRM such as green selective staffing, green training, green empowerment, green rewards, green career opportunities, green teamwork, green work-life balance, and green participation in decision making. Theoretical contributions and avenues for future research are discussed in the paper.
\end{abstract}

Keywords: green human resource management; green recovery performance; green voice behavior; job satisfaction; proactive pro-environmental behaviors; task-related pro-environmental behaviors; work engagement

\section{Introduction}

In a milieu that is becoming increasingly competitive, management of hospitality and tourism companies has started to acknowledge the importance of employees' pro-environmental behaviors (PEBs) to achieve environmental sustainability goals [1]. More specifically, service providers in the hospitality and tourism industry now realize that they should protect the environment, take advantage of green technology, have a careful consumption of water and energy, reduce waste, and enforce pro-active organizational learning to gain a sustainable competitive advantage and contribute to the establishment of environmentally sustainable economies [2-5]. For instance, the Accor hotels' environmental footprint consists of a number of issues such as carbon footprint and energy consumption, water consumption and eutrophication, and biodiversity footprint [6]. The commuter assistance program in the Walt Disney Company provides employees with incentives to display eco-friendly behaviors (e.g., reduction of traffic congestion and gas emission) [7]. Singapore Airlines, which has been part of the Sustainable 
Aviation Fuel Users Group since 2011, always tries to reduce its carbon footprint and contribute to global environmental issues through the establishment of green workplaces, energy and resource conservation, and utilization of eco-efficient aircrafts [8]. Marriott's sustainability goals for 2025 and beyond are "reduction of water intensity by $15 \%$, reduction of carbon intensity by $30 \%$, and reduction of waste to landfill by $45 \%$ " [9]. The sustainability goals of the abovementioned companies cannot be accomplished without the involvement of employees in the process.

Task-related PEBs, proactive PEBs, green recovery performance, and green voice behavior can be grouped under PEBs [10-13]. Task-related PEBs refer to " ... the extent to which employees complete their required work tasks in environmentally friendly ways" [10] (p. 157), while proactive PEBs highlight "... the extent to which employees take initiative to engage in environmentally friendly behaviors that move beyond the realm of their required work tasks" [10] (p. 158). Based on the definition of service recovery performance given by Babakus et al. [14] and consistent with the work of Darban et al. [15], our study defines green recovery performance as employees' abilities and actions to resolve a failure associated with environmentally unfriendly activities to the satisfaction of the customer. Borrowing the definition of voice behavior from Van Dyne and LePine [16], our study defines green voice behavior as making novel suggestions for environmentally friendly activities and recommending changes to standard procedures designed for green activities even when others disagree.

Employees can exhibit the abovementioned PEBs as a result of management's investment in green human resource practices. This highlights the importance of green human resource management (GHRM), which is related to managing human resources and providing human resource practices based on environmental management [17]. Green recruitment and selection, green training, green empowerment, green rewards, green performance assessment, and green involvement in decision making process can be studied under the GHRM system $[13,17,18]$. However, there is no consensus about the indicators of GHRM in the hospitality and tourism literature. This is because of the fact that empirical studies have utilized different indicators, e.g., [11,12,19].

Green human resource practices encourage employees to be involved in the protection of the environment and various control activities during the operational process [20]. As persuasively discussed by Amrutha and Geetha [13], employees exhibit PEBs as a result of their personal initiatives and green human resource practices in the company. Work engagement and job satisfaction can serve as the mediators linking GHRM to the previously mentioned PEBs. Work engagement, which is represented by "vigor", "dedication", and "absorption", is a motivational construct and engenders positive outcomes [21]. Research reports that employees" work engagement exerts a positive influence on their job performance [22,23]. Job satisfaction refers to "the pleasurable emotional state resulting from the appraisal of one's job as achieving or facilitating the achievement of one's job values" [24] (p. 316). Unlike the association between work engagement and job performance, research does not seem to delineate consistent findings regarding the effect of job satisfaction on job performance $[25,26]$. An exploration made in the relevant literature reveals that there is a dearth of evidence about whether GHRM can be linked to PEBs via non-green variables such as work engagement and job satisfaction. Having an understanding of these relationships is significant because the relationship of GHRM to non-green workplace outcomes has received little attention [27].

Against the above backdrop, our paper proposes a conceptual model of GHRM. Specifically, our study aims to identify the indicators of GHRM for the hospitality and tourism industry. Work engagement and job satisfaction are the underlying mechanisms linking GHRM to four organizationally valued PEBs such as task-related PEBs, proactive PEBs, green recovery performance, and green voice behavior.

By proposing a conceptual model of GHRM, our paper aims to decidedly address three questions:

(1) What are the potential indicators of GHRM for the hospitality and tourism industry?

(2) What is (are) the underlying mechanism(s) relating GHRM to multiple PEBs?

(3) Why is it important to utilize at least two mediating mechanisms linking GHRM to multiple PEBs? 
In the next section we delineate the conceptual model of GHRM and the literature review leading to specific propositions based on five theoretical underpinnings as well as evidence in the relevant literature. We conclude the paper with theoretical contributions and implications for future research and business practice.

\section{A Proposed Conceptual Model of Green Human Resource Management}

A careful examination of the relevant literature demonstrates that there is no consensus about the indicators of GHRM or green human resource practices though several review studies have identified the indicators of GHRM. For instance, Yong et al. [28] reported that green recruitment, green training, green performance management, and green rewards were widely used as the indicators of GHRM. In addition to the aforesaid indicators, Pham et al. [29] demonstrated that job description/analysis, performance management, organizational culture, the role of unions in environmental management, organizational learning, and green healthy and safety were among the GHRM practices. Accordingly, our study aims to contribute to the literature through the identification of the indicators of GHRM in the hospitality and tourism industry.

Employees' favorable perceptions of human resource practices trigger their work engagement or job satisfaction, which in turn engenders task performance, extra-role performance, service recovery performance, and/or innovative behavior [14,30-32]. These practices also lead to the accomplishment of competitive advantage. Although there are studies about employees' PEBs, very little is known about the mechanisms underlying GHRM to PEBs. This is likely to unravel the black box between GHRM and PEBs. In light of this reasoning, we use work engagement and job satisfaction as the two mediators linking GHRM to employees' task-related PEBs, proactive PEBs, green recovery performance, and green voice behavior.

Using a single mediator may lead to the problem of " .. discovering specious mediators, mediators that appear to channel an effect but do not in fact do so" [33] (p. 1728). This has been underscored in a recent empirical study about ethical leadership [34]. To avoid such a potential problem, our study uses work engagement and job satisfaction as the two mediators relating GHRM to employees' PEBs.

In addition, Shen et al. [27] cogently argue that the linkage between GHRM and non-green positive workplace outcomes remains largely unexplored. Though limited in number, there is evidence illustrating that green- and environmental-related variables act as a mediator of the effect of GHRM on PEBs [2]. However, management has to know whether its green initiatives, GHRM, and/or environmental management program fosters employees' non-green positive workplace attitudinal and/or behavioral outcomes.

\subsection{Theoretical Framework}

Yong et al. [28] propose that theories such as social exchange theory (SET) and the Ability-Motivation-Opportunity (AMO) framework would provide a better understanding of how GHRM is linked to various attitudinal and behavioral consequences. Our study goes one step further and uses five theoretical underpinnings. That is, our study utilizes the AMO framework [35], SET [36], social information processing (SIP) theory [37], the happy-productive thesis [38], and reformulation of attitude theory [39] as well as evidence in the relevant literature to develop the conceptual model of GHRM.

The conceptual model of GHRM proposed in our paper can be comprehended in light of the AMO framework, which is considered to be one of the most dominant theories in explaining the effects of human resource practices on employee and organizational outcomes [35]. According to this theory, human resource initiatives, which enhance employees' abilities and their motivation to do work, result in effective performance consequences [40]. Jiang et al. [41] classified human resource practices into skill-, motivation-, and opportunity-enhancing human resource practices. For example, employees are likely to be highly work-engaged and therefore display better performance outcomes when they participate in training (skill-enhancing) programs to develop their skills and knowledge about how 
to use their authority (opportunity-enhancing) to respond to customer problems [40]. They receive recognition and rewards (motivation-enhancing) and/or take advantage of career opportunities (motivation-enhancing) as a result of their quality work performance. Management's investment in various green human resource practices is a sign of developing employees' knowledge, skills, and abilities toward environmental sustainability as well as a sign of motivating them to practice empowerment for the resolution of environmentally specific problems at the individual and team levels.

SET proposes that the company and employees enjoy a trusting and quality relationship when they show adherence to the rules of exchange [36]. When employees perceive that management invests in green human resource practices, they feel obliged to repay the company via work engagement and job satisfaction. That is, employees are highly work-engaged and are motivated to contribute to the company by exhibiting PEBs.

SIP theory states, " . . individuals, as adaptive organisms, adapt attitudes, behavior, and beliefs to their social context and to the reality of their own past and present behavior and situation" [37] (p. 226). Employees gather information about the social environment where they work and develop relationships. They use green information about management's investment in green human resource practices as cues to develop their attitudes (e.g., job satisfaction) and behaviors (i.e., PEBs).

According to the happy-productive thesis, happy employees show more sensitivity to positive events and remember favorable events [38]. Then we surmise that happy employees are satisfied with their job as a result of management's investment in green human resource practices and therefore exhibit PEBs.

Reformulation of attitude theory posits that individuals appraise past, present, and future outcomes [39]. Employees who find that management really invested (past outcome), invests (present outcome), and/or will invest (future outcome) in GHRM such as green training, green empowerment, and green selective staffing (cognitive evaluation) show an emotional response to these practices in the form of work engagement and job satisfaction. These employees in turn engage in PEBs (behavioral response).

\subsection{Green Human Resource Management and Its Indicators}

The extant literature presents evidence about the impacts of the indicators of GHRM, the individual effects of human resource practices, or the impacts of overall high-performance work systems (HPWSs) on employee performance through several mediating mechanisms. For example, Sun et al.'s [42] research in the hotel industry in China documented that HPWSs were positively linked to productivity through service-oriented organizational citizenship behavior. In another research in Taiwan, it was reported that service and justice climates completely mediated the impacts of HPWSs on service-oriented organizational citizenship behavior [43]. Karatepe and Karadas's [40] work in Romania showed that training and empowerment partly mediated the impact of job embeddedness on extra-role performance, while empowerment and rewards partly mediated the effects of empowerment and rewards on service recovery performance. Karadas and Karatepe's [30] research in the same country indicated that HPWSs were linked to extra-role performance indirectly via work engagement, while work engagement partly mediated the association between HPWs and creative performance.

Safavi and Karatepe [44] found that HPWSs, as manifested by several practices such as selective staffing, training, and work-life balance, completely mediated the effect of career adaptability on hotel employees' creative and extra-role performances in Iran. A study of hotel employees in India indicated that work engagement partly mediated the effects of HPWSs on service innovative behavior [45].

An immediate conclusion that can be made from the aforesaid studies is that an overall measure of HPWSs, the indicators of HPWSs, or the individual dimensions of HPWSs can be used to ascertain their effects on employee outcomes.

The conceptual model of GHRM is presented in Figure 1. GHRM is still a hot topic $[13,15,27,46]$, which highlights " ... the alignment of diverse practices destined for human resource management (recruiting, selection, training, performance evaluation, rewards) to a company's green management 
objectives ... " [47] (p. 318). Simply put, GHRM is the result of an injection of environmental/green management to human resource management. As depicted in Figure 1, green selective staffing, green training, green empowerment, green rewards, green career opportunities, green teamwork, green work-life balance, and green participation in decision making are identified as the indicators of GHRM. The authors of this study had a full agreement on the abovementioned indicators of GHRM based on an extensive review of the relevant writings and the green initiatives of a number of service companies [48]. Having GHRM in place is so critical because human resource practices are needed for the effective implementation of an environmental management system [46]. This implicitly underlines the role of human resource practices that would give rise to PEBs.

On the other hand, management is expected to "walk the talk". More specifically, organizational hypocrisy refers to the inconsistency between formal structures of an organization and their daily use [49]. This difference between the talk and the action is known as greenwashing [50]. A past study showed that such inconsistency increased employees' emotional exhaustion and quitting intentions [51] as well as counterproductive work behaviors [52]. Managers may claim that they have formulated and implemented GHRM strategies with the company. When employees find that the company is really not committed to environmental protection (greenwashing), such perception may influence their work engagement and job satisfaction deleteriously and therefore may reduce their willingness to engage in PEBs.

Environmentally-specific servant leadership might be a remedy to the abovementioned problem [53]. Servant leaders pay utmost attention to the interests of their followers and act as role models for them. Environmentally-specific servant leadership might motivate these followers to imitate the attitudes and behaviors of their role models by engaging more in eco-friendly behaviors. 


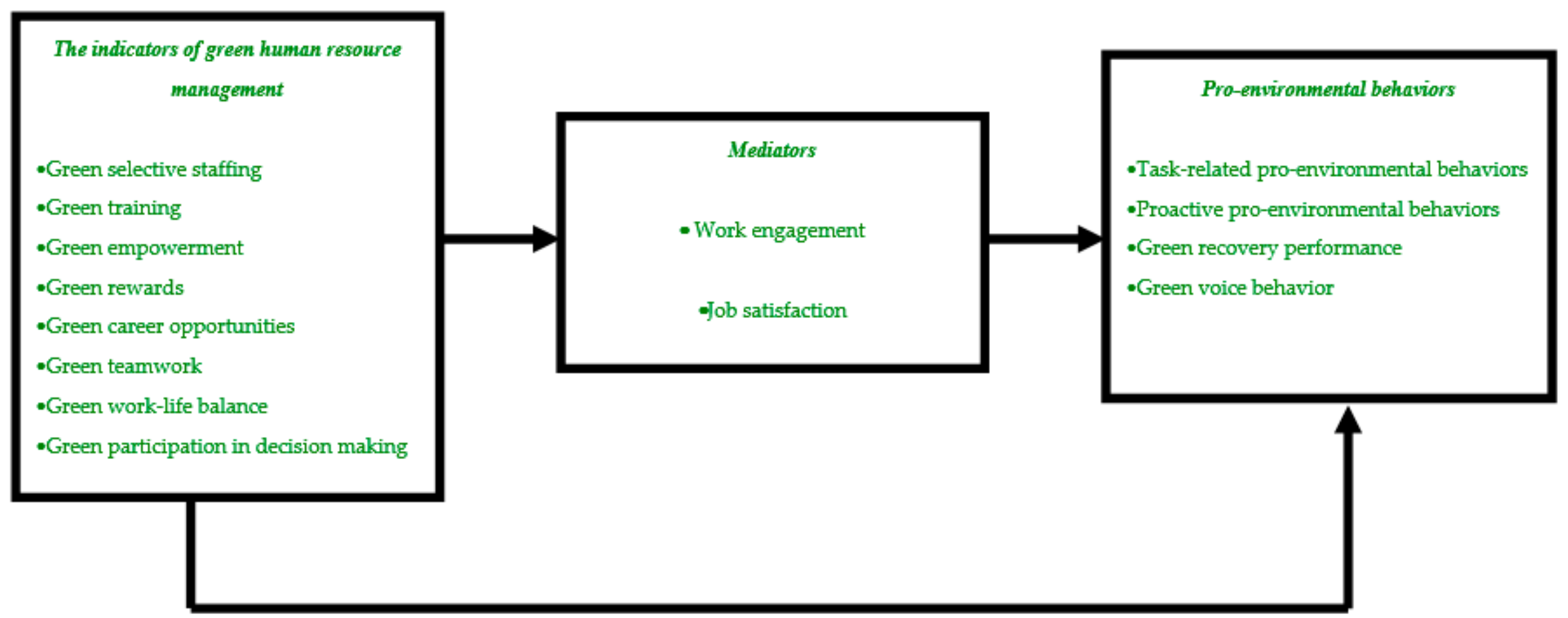

Figure 1. A Proposed Conceptual Model of Green Human Resource Management. 


\subsubsection{Green Selective Staffing}

Selective staffing is an important practice for hiring talented individuals [54,55]. Selective staffing is used to hire the right individual for the vacant position via various strict procedures [56]. To find the most suitable individuals, management can take advantage of social networks and e-recruitment and selection [57]. A search made in the environmental sustainability literature highlights the importance of selective staffing for the effective implementation of environmental management. For instance, Jabbour and Santos's [58] prior writing illustrated that organizations considered environment a criterion during the hiring process. In an empirical study conducted in the manufacturing industry in China, Zhao et al. [59] argue that companies can take advantage of green criteria to select the candidates whose environmental values fit those of the organization. Ren et al.'s [60] review implicitly documents that selective staffing was one of the most widely investigated human resource practices in the GHRM literature. Bombiak and Marciniuk-Kluska [61] convincingly discuss that companies should pay attention to the selection of the candidates who would display eco-friendly behaviors. They further discuss that such a practice can make the company a green employer which would in turn lead to the acquisition of talented individuals. Tuan's [62] study carried out in the hospitality industry in Vietnam also identified selective staffing as one of the elements of discretionary human resource practices.

\subsubsection{Green Training}

Training, empowerment, and rewards have been reported to be consistent indicators of HPWSs $[14,56,63]$. Training is needed to improve both job-related and behavioral skills of employees at the bottom line so that they can manage customer requests and problems satisfactorily [14]. In the current environmental sustainability research, training is regarded as one of the major factors for the effective implementation of environmental management $[58,64]$. Green training enables employees to have a full understanding of the significance of environmental protection and increase their environmental sensitivity and encourages them to display PEBs [64,65]. Green training can make employees pay utmost attention to less consumption of water and energy, reduction of waste, utilization of renewable materials, and use of recycled materials. To achieve this, both formal and informal training can pay dividends. The presence of formal and informal training sends a strong signal to employees about the company's commitment to environmental sustainability and the successful implementation of GHRM. Importantly, employees' involvement in the formulation of environmental goals and strategies would lead to the successful implementation of environmental management programs. Evidence obtained from the industry revealed that training was one of the human resource practices used for Hilton's we care! Program [66]. This program enabled the company to reduce water and energy consumption as well as $\mathrm{CO}_{2}$ emissions. The Starbucks Greener Apron Program enables employees to participate in inspiring sustainability training programs and learn how to be more sustainable everyday [67]. In addition, Wyndham Hotels' Green Certification Program centers on the education of both employees and guests to raise awareness about environmental sustainability [68].

Training was reported to be one of the most widely sought human resource practices in the extant GHRM research [60]. For example, in a study carried out in India, Srivastava and Shree [69] reported that green training strengthened the positive association between hotel employees' green involvement and corporate social responsibility. Luu's [11] research in Vietnam showed that training was one of the indicators of green human resource practices. Kim et al.'s [2] empirical investigation in the hotel industry in Thailand documented that training was an important tool to promote environmental management in the organization. In another study carried out in Vietnam, Pham et al. [70] reported that green training was one of the predictors of employees' commitment to the environment, organizational citizenship behavior for the environment, and corporate environmental performance. The positive linkage between green training and employees' environmental commitment was also reported in another study conducted in Vietnam [71]. 


\subsubsection{Green Empowerment}

Empowerment, which refers to "the freedom and ability to make decisions and commitments" [72] (p. 67), is one of the indicators of HPWSs [14,56,63]. Relinquishing control over many aspects of the service delivery process enables employees to obtain the authority so that they can handle customer requests and problems successfully [14]. Employees can practice empowerment provided that they participate in training programs which focus on the effective utilization of empowerment based on customer and management expectations. The availability of green empowerment encourages employees to engage in PEBs [11]. In their systematic review of GHRM, Tariq et al. [73] persuasively discuss that green empowerment motivates employees to engage in green practices, which would help the organization accomplish a competitive advantage. Tuan [74] also highlights the critical role of green empowerment implemented by environmentally-specific servant leadership. With empowerment, management can motivate employees to use personal initiatives and engage in eco-friendly behaviors.

\subsubsection{Green Rewards}

Rewarding employees for their green behaviors is one of the indicators of GHRM [11,29]. This is also underlined in Ren et al.'s [60] review. Not surprisingly, Renwick et al. [17] discuss that companies utilizing environmental rewards enhance employees' willingness to exhibit eco-friendly behaviors. By empowering employees, management expects them to do a great job with customers for achieving satisfaction and effective recovery. Employees' successful practices in this process should be recognized and rewarded. The availability of financial and non-financial rewards in the organization sends strong signals to employees that PEBs are encouraged, appreciated, and rewarded.

In empirical terms, Pham et al.'s [71] study demonstrated that green recognition and reward was one of the determinants of employees' commitment to the environment. This is also shown in Huo et al.'s [20] study that employees were rewarded for their green creativity.

\subsubsection{Green Career Opportunities}

One of the indicators of HPWSs is career opportunities [30,56]. Employees' perceived career opportunity is described as "... the degree to which work assignments and job opportunities that match their career interests and goals are available within their current organization" [75] (p. 488). The ones who contribute to the environmental performance of the company would seek opportunities for their career progress within the same company. We believe that the other components of GHRM such as green training cannot be translated into green actions without green career opportunities.

Bauer and Aiman-Smith's [76] past study illustrated that using messages about the issue of environmental sustainability in recruitment brochures would positively influence the job candidates who did not think that they displayed PEBs. In Ren et al.'s [60] review of GHRM, career advancement is shown as one of the components of the GHRM system. However, the preponderance of the empirical studies has not incorporated it into GHRM $[28,29,77]$. This is surprising because employees who are trained, empowered, and rewarded for their green activities would seek the opportunities for career progress in the organization. To acquire and retain talented employees, management has to offer a bundle of career opportunities during the selection process. Otherwise, such employees are no longer willing to be one of the strategic partners of the organization and help the company accomplish organizational objectives. With this in mind, management of companies should offer attractive career opportunities to talented employees for their environmental commitment, green creativity, and eco-friendly behaviors.

\subsubsection{Green Teamwork}

Teamwork is associated with employees' willingness to cooperate in a workgroup or a team [78]. Green teams are needed to find solutions to environmental problems at work or are involved in implementing environmental management programs in the company [79]. Unlike green career 
opportunities, a number of review and conceptual studies as well as empirical pieces on GHRM have identified green teamwork as one of the indicators of GHRM. For example, Renwick et al. [17] have highlighted the importance of green or environmental action teams, which would lead to employees' involvement in environmental initiatives. Teixeira et al. [47] discuss that "organizational culture and teamwork", "top management support", and "more technical green management practices" are the dimensions that appear to convert training with an environmental focus into proactive green management. Jabbour and Jabbour [79] argue that in an organization where green culture is established, teamwork and empowerment are needed to make decisions about complex issues and new perspectives on green supply chain management. In Amrutha and Geetha's [13] systematic review of GHRM, it has been highlighted that green teams can encourage other employees to engage in eco-friendly behaviors.

\subsubsection{Green Work-Life Balance}

Work-life balance is defined as "... an individual's subjective appraisal of the accord between his/her work and non-work activities and life more generally" [80] (p. 2728). Work-life balance is an important tool to attract talented individuals. For example, Rodríguez-Sánchez et al. [81] proposed that non-monetary benefits in the form of work-life balance are related to retention of talented individuals. Safavi and Karatepe [44] identified work-life balance as one of the indicators of HPWSs. When applied to environmental sustainability, almost one decade ago, Muster and Schrader [82] coined the term "green work-life balance" and cogently argued that green work-life balance can be studied under GHRM. However, the extant literature is bereft of evidence about green work-life balance as one of the indicators of GHRM.

Green work-life balance refers to "... reconciliation of working life and private life with regards to environmental values, attitudes and behavior. It comprises mutual enforcement and harmonization of environmentally friendly orientations in private life and working life" [82] (p. 148). Employees gain experiences about green activities in their work and nonwork life. That is, employees who gain experiences about green activities or environmental sustainability in the work and nonwork domains can take advantage of them to enrich each other. Such employees can make green contributions to the company by engaging in eco-activities at elevated levels. In Amrutha and Geetha's [13], Pham et al.'s [29], and Ren et al.'s [60] review of GHRM, work-life balance has been shown to be incorporated into the GHRM system.

\subsubsection{Green Participation in Decision Making}

Employees, who are allowed to participate in decision making, find the nature and type of their tasks significant and meaningful. As reported by Jackson [83], employees who contribute to the company via participation in decision making can handle role stressors. Employees promote greening of the organization by participating in decision making about environmental sustainability. Such employees can provide novel ideas about how the company may enhance the green environment and share its strategies and practices about environmental sustainability with the relevant parties such as customers. This is especially important for employees at the bottom line because they have frequent interactions with customers and are significant sources of information about customer problems and expectations [30]. Similarly, Amrutha and Geetha [13] argue that employees' participation in the decision making process triggers their green behaviors or PEBs.

The previously mentioned discussion and findings implicitly suggest that GHRM can be represented by green selective staffing, green training, green empowerment, green rewards, green career opportunities, green teamwork, green work-life balance, and green participation in decision making. This leads to the following proposition:

Proposition 1. GHRM is manifested by green selective staffing, green training, green empowerment, green rewards, green career opportunities, green teamwork, green work-life balance, and green participation in decision making. 


\subsection{Work Engagement and Job Satisfaction}

The findings of a case study (Hotel Floyd) demonstrated that employees took pride in providing information to customers about the hotel's green initiatives and became more loyal to the hotel [84]. It appears that employees display job satisfaction as a result of green initiatives and are embedded in their job. However, evidence about the relationship of GHRM to non-green positive workplace outcomes is scarce [27]. It appears that there is only one empirical study, which has linked GHRM to job satisfaction [85]. It also appears that none of the review studies has presented work engagement as one of the motivational outcomes $[13,28,29,60]$. This is surprising because according to the recent Gallup Report in 2019,35\% of employees were engaged in their work, while $13 \%$ were actively disengaged from their work, and 52\% were in the "not engaged" category [86]. Therefore, it is important to incorporate both work engagement and job satisfaction into the conceptual model as the two underresearched motivational outcomes of GHRM.

Work engagement is associated with "a positive, fulfilling, work-related state of mind that is characterized by vigor, dedication, and absorption" [87] (p. 74). An abundant number of studies have investigated the antecedents and outcomes of job satisfaction, e.g., [88]. This also seems to be true for work engagement. Studies have also documented that work engagement and job satisfaction are empirically distinct variables, e.g., [89].

It has been reported that the presence of human resource practices or HPWSs (e.g., training, empowerment, staffing, teamwork) fosters employees' work engagement and job satisfaction [30,55]. However, Kloutsiniotis and Mihail's [55] recent work has highlighted the usefulness of HPWSs in activating work engagement.

A search made in the environmental sustainability and hospitality and tourism literatures delineates some evidence about whether GHRM boosts employees' work engagement and job satisfaction. For instance, Zibarras and Coan's [90] investigation in the United Kingdom implicitly demonstrates that human resource practices in organizations are used to a great extent to motivate employees to exhibit PEBs. Lack of GHRM or ineffective implementation of GHRM in organizations raises the question of whether top management of such organizations is really committed to environmental sustainability. Pinzone et al.'s [85] study in the Italian health sector illustrated that green training fostered employees' job satisfaction. Darban et al. [15] reported that hotel employees' favorable perceptions of GHRM boosted their work engagement. That is, employees who find that management of the company really invests in GHRM such as green training, green teams, and/or green selective staffing are highly work-engaged. Amrutha and Geetha [13] cogently discuss that employees are interested in working in companies where there are practices such as "green employee succession planning". However, management should consider the potentially negative indirect effects of green practices on employees' job satisfaction due to job intensity or work overload that can be caused by the implementation of environmental management program [91].

In light of the AMO framework, SET, and SIP theory, we propose that management of hospitality and tourism companies investing in eight interrelated indicators of GHRM can activate employees' work engagement and job satisfaction. More specifically, the presence of green human resource practices enhances employees' sensitivity to environmental sustainability and green management. Consistent with the AMO framework, these practices foster their knowledge, skills, and abilities related to environmental issues [35]. As a result of this, employees exhibit work engagement and job satisfaction.

As SET contends, both the company and employees enjoy a trusting and quality connection with each other when they comply with the rules of exchange [36]. Under these circumstances, employees feel obliged to reciprocate via heightened work engagement and job satisfaction due to the presence of green human resource practices. This is also supported by SIP theory that employees can utilize management's intent to invest in green human resource practices as cues in their social work environment [37]. This increases their work engagement and job satisfaction.

Trying to select individuals whose environmental values fit those of the organization through green and online recruitment procedures delineates management's investment in green selective 
staffing. The presence of green training programs with a focus on green empowerment practices and effective green team performance and rewards for employees' green behaviors at the individual and team levels sends strong signals to employees that management is highly committed to environmental sustainability. Offering career opportunities to employees in return for their green behaviors or their sensitivity to environmental sustainability is a sign of management's investment in GHRM. Enabling employees to participate in decision making concerning the company's environmental management program and provide feedback to management about how to enhance the environmental or green strategies motivates them to concentrate on their tasks and makes them satisfied with their job. Such employees can transfer their green experiences to their life domain and engage in green behaviors or display eco-friendly behaviors. The previously mentioned information and discussion leads to the following propositions:

Proposition 2a. GHRM, as manifested by green selective staffing, green training, green empowerment, green rewards, green career opportunities, green teamwork, green work-life balance, and green participation in decision making, fosters employees' work engagement.

Proposition 2b. GHRM, as manifested by green selective staffing, green training, green empowerment, green rewards, green career opportunities, green teamwork, green work-life balance, and green participation in decision making, fosters employees' job satisfaction.

\subsection{Differential Pathways}

As discussed above, we incorporate work engagement and job satisfaction as the two underresearched non-green positive workplace outcomes into the model. This void is evident in review studies and recent empirical pieces $[13,28,29,60]$. Kim et al. [92] claim that " ... most hospitality employees consider PEBs as expressions of their true selves, increases their feelings of engagement, and, consequently nurtures persistent efforts to perform PEBs" (p. 64). This suggests a positive linkage between work engagement and PEBs. Providing employees with green human resource practices motivates them to pay more attention to environmental sustainability and exhibit PEBs. These green human resource practices can increase employees' work engagement and job satisfaction and therefore exhibit PEBs. Reformulation of attitude theory offers guidelines to develop these linkages [39]. Specifically, employees' cognitive evaluation of management's investment in green human resource practices results in emotional responses such as work engagement and job satisfaction. This is because employees evaluate such practices as positive events or outcomes in the workplace. Employees who are work-engaged and are satisfied with their job as a result of GHRM exhibit PEBs such as task-related PEBs, proactive PEBs, green recovery performance, and green voice behavior.

The extant literature presents empirical studies about GHRM and its potential consequences, e.g., $[13,60]$. As mentioned earlier, what is missing in the literature is a parsimonious model that unravels the underlying mechanisms relating GHRM to multiple pro-environmental behaviors. The environmental sustainability literature as well the hospitality and tourism literature are devoid of evidence regarding the effectiveness of work engagement versus job satisfaction in the association between the indicators of GHRM and multiple PEBs such as task-related PEBs, proactive PEBs, green recovery performance, and green voice behavior. This is a significant void because service or hospitality and tourism companies need employees who are highly motivated via the successful implementation of GHRM so that they can exhibit PEBs at elevated levels.

A recent study carried out at Chinese coal companies, Huo et al. [20] demonstrated that GHRM partly mediated the impact of commitment to human resource management on green creativity. In another study in the manufacturing industry in Pakistan, Malik et al. [93] reported that several components of GHRM such as recruitment, selection, and rewards were positively related to sustainability. Based on evidence resulting from the study conducted in high-polluting industries in China, Zhao et al. [59] found that GHRM was a mediator between a proactive environmental strategy 
and environmental reputation. Another study done in different industries in China, Zhang et al. [12] reported that "employee life-cycle", "education and training", and "manager involvement" as the components of GHRM were positively associated with green in- and extra-role performance through the mediating role of information need. The findings emerging from a study carried out in medical firms in China indicated that GHRM and green passion serially mediated the impact of transformational leadership on green creativity [65].

Darban et al. [15] found that work engagement completely mediated the effect of GHRM on absenteeism and green recovery performance. Chaudhary's [94] recent study in an Indian sample indicated that organizational prestige and organizational attractiveness sequentially mediated the linkage between GHRM and job pursuit intentions. Another study by Chaudhary [77] in the automobile industry in India documented that organizational identification partly mediated the impact of GHRM on task-related and voluntary green behaviors.

In this study, we argue that the mediation impact of work engagement in the linkage between GHRM and multiple PEBs may be stronger than the mediation effect of job satisfaction. Evidence suggests that the availability of HPWs triggers employees' work engagement [30]. Work engagement is a more proximal variable to job performance [95]. Evidence supports the notion that work engagement is a significant determinant of task performance, creative performance, service recovery performance, extra-role performance, and adaptive performance [30,95-97]. Though the happy-productive thesis lends support to the linkage between job satisfaction and job performance [38], Bowling's [25] meta-analytic work presents the finding that the association between job satisfaction and job performance is mostly spurious. Hence, the following propositions are advanced:

Proposition 3a. GHRM, as manifested by green selective staffing, green training, green empowerment, green rewards, green career opportunities, green teamwork, green work-life balance, and green participation in decision making, is linked to task-related PEBs, proactive PEBs, green recovery performance, and green voice behavior through work engagement.

Proposition 3b. GHRM, as manifested by green selective staffing, green training, green empowerment, green rewards, green career opportunities, green teamwork, green work-life balance, and green participation in decision making, is linked to task-related PEBs, proactive PEBs, green recovery performance, and green voice behavior through job satisfaction.

Proposition 3c. The mediation impact of work engagement in the association between GHRM and the abovementioned PEBS may be stronger than the mediation impact of job satisfaction due to the potential spurious relationship between job satisfaction and performance outcomes.

\section{Conclusions}

\subsection{Theoretical Contributions}

The effective implementation of human resource management plays a critical role in organizational performance [34]. The increased awareness of environmental sustainability has forced companies to incorporate environmental issues into their mission, objectives, and strategies. This is also true for the injection of environmental sustainability to human resource aspects of the whole process in the hospitality and tourism industry. With this realization in mind, our paper set out to develop a parsimonious model of GHRM to address several voids in the environmental sustainability literature as well as in the hospitality and tourism literature. First, it has been highlighted that work engagement or job satisfaction acts as a mediator of the effects of human resource practices on employees' performance consequences $[14,32]$. Yet there is a paucity of evidence appertaining to the underlying mechanism(s) through which GHRM is related to employees' PEBs. Accordingly, our paper uses work engagement 
and job satisfaction as the underlying mechanisms through which GHRM influences employees' PEBs. This helps us unravel the black box between GHRM and multiple PEBs.

Second, a synthesis of the current writings reveals that human resource practices such as recruitment and selection, training, empowerment, or employee involvement can be adapted to green human resource practices [28,29]. However, there is still no consensus about which indicators or components can be incorporated into the GHRM system. Therefore, based on synthesis of the relevant writings and green human resource practices of the leading companies in the service industries, our paper identified eight GHRM practices, which are green selective staffing, green training, green empowerment, green rewards, green career opportunities, green teamwork, green work-life balance, and green participation in decision making.

Third, we used the abovementioned two mediators in the conceptual model of GHRM proposed in this paper. When the two mediators are assessed simultaneously, it would be possible to ascertain whether two of them still remain useful in explaining the impact of GHRM on multiple PEBs [34].

\subsection{Directions for Future Research}

As Ren et al. [60] state in their review, "With the continued awareness of environmental sustainability, GHRM is now clearly a legitimate field of academic pursuit" (p. 798). Empirical studies are needed to test the linkages shown in the conceptual model. For example, evidence is needed for the proposition that the indicators of GHRM may enhance work engagement more than job satisfaction. This call for research is important because without employees' involvement in the process, management is unable to achieve environmental sustainability goals. The database can be broadened by conducting a cross-national study. Data can be collected in different countries such as Turkey, the United States, and Japan to assess the linkages proposed in the conceptual model.

Additional studies are needed to understand the antecedents, mediators, moderators, and consequences of GHRM at the organizational level and/or individual level. The type of leadership practiced in the company (e.g., servant leadership, authentic leadership) as well as employees' personality traits such as self-efficacy, competitiveness, and emotional intelligence can be considered as the antecedents of GHRM and can be incorporated into the conceptual model, e.g., $[53,95,98]$. Future studies can focus on the effects of recent advances in technology on GHRM. For example, future research can examine the moderating role of virtual assistants on the association between GHRM and employees' PEBs.

Future research can test employees' green experiences as a moderator of the effect of GHRM on multiple PEBs. This can also be considered for the moderating role of green experiences on the association between GHRM and work engagement and job satisfaction. Future research may focus on other types of non-green positive workplace variables (e.g., job embeddedness and career satisfaction) as the mediators relating GHRM to multiple PEBs.

To control the risk of common method variance, future studies should use both procedural and statistical remedies. For instance, time-lagged design as well as supervisor ratings for PEBs would be useful. On a closing note, we hope that the conceptual model of GHRM proposed in the present study will inspire other researchers to pursue these relevant issues and respond to calls for research in the future.

\subsection{Implications for Business Practice}

In today's competitive marketplace, a number of hospitality and tourism companies are now sensitive to environmental sustainability and green management. The conceptual model of GHRM proposed in our paper can be used in the following ways. First, management can utilize the indicators of GHRM when it wants to make decisions on how to invest in and/or foster green human resource practices. Second, management should not focus only on one of the PEBs. Task-related PEBs, proactive PEBs, green recovery performance, and green voice behavior are important in their own right. Third, management should make sure that the successful implementation of GHRM triggers employees' 
work engagement. This is so important since service companies are beset with plenty of employees at the bottom line who are (actively) disengaged from their work. Therefore, management needs to retain work-engaged employees as a result of GHRM. Fourth, management can take advantage of recent technology and artificial intelligence [99] to inject the environmental sustainability programs and green initiatives to both customers and employees. For example, chatbots can be used to convey such information to them at any time. Using chatbots, it would be possible to notify employees about the environmental sustainability program [100].

Author Contributions: E.A.: Literature review, conceptualization, and contribution to the preparation and revision of the paper; O.M.K.: Idea generation, literature review, conceptualization, development of the conceptual model and propositions, writing the paper, and revising the paper; H.R.: Literature review and contribution to the preparation and revision of the paper; T.A.: Literature review and contribution to the revision of the paper. All authors have read and agreed to the published version of the manuscript.

Funding: This research received no funding.

Conflicts of Interest: The authors declare no conflict of interest.

\section{References}

1. Chung, K.C. Green marketing orientation: Achieving sustainable development in green hotel management. J. Hosp. Mark. Manag. 2020, 29, 722-738. [CrossRef]

2. Kim, Y.J.; Kim, W.G.; Choi, H.-M.; Phetvaroon, K. The effect of green human resource management on hotel employees' eco-friendly behavior and environmental performance. Int. J. Hosp. Manag. 2019, 76, 83-93. [CrossRef]

3. Karatepe, O.M.; Rezapouraghdam, H.; Hassannia, R. Job insecurity, work engagement and their effects on hotel employees' non-green and nonattendance behaviors. Int. J. Hosp. Manag. 2020, 87, 102472. [CrossRef]

4. Sharma, T.; Chen, J.; Liu, W.Y. Eco-innovation in hospitality research (1998-2018): A systematic review. Int. J. Contemp. Hosp. Manag. 2020, 32, 913-933. [CrossRef]

5. Wang, Y.; Shi, S.; Chen, Y.; Gursoy, D. An examination of market orientation and environmental marketing strategy: The case of Chinese firms. Serv. Ind. J. 2019, 39, 1046-1071. [CrossRef]

6. Accor Hotels' Environmental Footprint. Available online: file://C:/Users/Administrator/Downloads/Accor Hotels\%20environmental\%20Foot\%20Print\%202016.pdf (accessed on 30 May 2020).

7. The Walt Disney Company. Environemntal Sustainability. Available online: https://thewaltdisneycompany.c om/environmental-sustainability/ (accessed on 8 June 2020).

8. Singapore Airlines' Environmental Efforts. Available online: https://www.singaporeair.com/en_UK/gb/flyin g-withus/our-story/giving-back/environmental-efforts/ (accessed on 8 June 2020).

9. Marriott: Sustainability Goals for 2025 and Beyond. Available online: https://www.ecolab.com/stories/marri ott-sustainability-goals-for-2025-and-beyond (accessed on 13 August 2020).

10. Bissing-Olson, M.J.; Iyer, A.; Fielding, K.S.; Zacher, H. Relationships between daily affect and pro-environmental behavior at work: The moderating role of pro-environmental attitude. J. Organ. Behav. 2013, 34, 156-175. [CrossRef]

11. Luu, T.T. Employees' green recovery performance: The roles of green HR practices and serving culture. J. Sustain. Tour. 2018, 26, 1308-1324. [CrossRef]

12. Zhang, Y.; Luo, Y.; Zhang, X.; Zhao, J. How green human resource management can promote green employee behavior in China: A technology acceptance model perspective. Sustainability 2019, 11, 5408. [CrossRef]

13. Amrutha, V.N.; Geetha, S.N. A systematic review on green human resource management: Implications for social sustainability. J. Clean. Prod. 2020, 247, 119-131. [CrossRef]

14. Babakus, E.; Yavas, U.; Karatepe, O.M.; Avci, T. The effect of management commitment to service quality on employees' affective and performance outcomes. J. Acad. Mark. Sci. 2003, 31, 272-286. [CrossRef]

15. Darban, G.; Karatepe, O.M.; Rezapouraghdam, H. Linking green human resource management to hotel employees' absenteeism and green recovery performance through work engagement. Manuscr. Submitt. Publ. 2020. submitted for publication.

16. Van Dyne, L.; LePine, J.A. Helping and voice extra-role behaviors: Evidence of construct and predictive validity. Acad. Manag. J. 1998, 41, 108-119. 
17. Renwick, D.W.S.; Redman, T.; Maguire, S. Green human resource management: A review and research agenda. Int. J. Manag. Rev. 2013, 15, 1-14. [CrossRef]

18. Tang, G.; Chen, Y.; Jiang, Y.; Paillé, P.; Jia, J. Green human resource management practices. Scale development and validity. Asia Pac. J. Hum. Resour. 2018, 56, 31-55. [CrossRef]

19. Yusoff, Y.M.; Nejati, M.; Kee, D.M.H.; Amran, A. Linking green human resource management practices to environmental performance in hotel industry. Glob. Bus. Rev. 2018, 21, 663-680. [CrossRef]

20. Huo, W.; Li, X.; Zheng, M.; Liu, Y.; Yan, J. Commitment to human resource management of the top management team for green creativity. Sustainability 2020, 12, 1008. [CrossRef]

21. Schaufeli, W.B.; Bakker, A.B.; Salanova, M. The measurement of work engagement with a short questionnaire: A cross-national study. Educ. Psychol. Meas. 2006, 66, 701-716. [CrossRef]

22. Kim, W.; Han, S.J.; Park, J. Is the role of work engagement essential to employee performance or 'nice to have'? Sustainability 2019, 11, 1050. [CrossRef]

23. Bayona, J.A.; Caballer, A.; Peiró, J.M. The relationship between knowledge characteristics' fit and job satisfaction and job performance: The mediating role of work engagement. Sustainability 2020, 12, 2336. [CrossRef]

24. Locke, E.A. What is job satisfaction? Organ. Behav. Hum. Perform. 1969, 4, 309-336. [CrossRef]

25. Bowling, N.A. Is the job satisfaction-job performance relationship spurious? A meta-analytic examination. J. Vocat. Behav. 2007, 71, 167-185. [CrossRef]

26. Cortini, M.; Converso, D.; Galanti, T.; Di Fiore, T.; Di Domenico, A.; Fantinelli, S. Gratitude at work works! A mixed-method study on different dimensions of gratitude, job satisfaction, and job performance. Sustainability 2019, 11, 3902. [CrossRef]

27. Shen, J.; Dumont, J.; Deng, X. Employees' perceptions of green HRM and non-green employee work outcomes: The social identity and stakeholder perspectives. Group Organ. Manag. 2018, 43, 594-622. [CrossRef]

28. Yong, Y.C.; Yusliza, M.-Y.; Fawehinmi, O.O. Green human resource management: A systematic literature review from 2007 to 2019. Benchmarking Int. J. 2019, 27, 20052027. [CrossRef]

29. Pham, T.N.; Hoang, H.T.; Phan, Q.P.T. Green human resource management: A comprehensive review and future research agenda. Int. J. Manpow. 2019. submitted for publication. [CrossRef]

30. Karadas, G.; Karatepe, O.M. Unraveling the black box: The linkage between high-performance work systems and employee outcomes. Empl. Relat. 2019, 41, 67-83. [CrossRef]

31. Zhang, M.; Zhu, C.J.; Dowling, P.J.; Bartram, T. Exploring the effects of high-performance work systems (HPWS) on the work-related well-being of Chinese hospital employees. Int. J. Hum. Resour. Manag. 2013, 24, 3196-3212. [CrossRef]

32. Macky, K.; Boxall, P. The relationship between 'high-performance work practices' and employee attitudes: An investigation of additive and interaction effects. Int. J. Hum. Resour. Manag. 2007, 18, 3196-3212. [CrossRef]

33. Fischer, T.; Dietz, J.; Antonakis, J. Leadership process models: A review and synthesis. J. Manag. 2017, 43, 1726-1753. [CrossRef]

34. Peng, A.C.; Kim, D. A meta-analytic test of the differential pathways linking ethical leadership to normative conduct. J. Organ. Behav. 2020, 41, 348-368. [CrossRef]

35. Boselie, P.; Dietz, G.; Boon, C. Commonalities and contradictions in HRM and performance research. Hum. Resour. Manag. J. 2005, 15, 67-94. [CrossRef]

36. Cropanzano, R.; Mitchell, M.S. Social exchange theory: An interdisciplinary review. J. Manag. 2005, 31, 874-900. [CrossRef]

37. Salancik, G.R.; Pfeffer, J. A social information processing approach to job attitudes and task design. Adm. Sci. Q. 1978, 23, 224-253. [CrossRef] [PubMed]

38. Wright, T.A.; Cropanzano, R. The Happy/Productive Worker Thesis Revisited. Research in Personnel and Human Resources Management; Martocchio, J.J., Ed.; Elsevier: Oxford, UK, 2007; Volume 26, pp. 269-307.

39. Bagozzi, R.P. The self-regulation of attitudes, intentions, and behavior. Soc. Psychol. Q. 1992, 55, $178-204$. [CrossRef]

40. Karatepe, O.M.; Karadas, G. The effect of management commitment to service quality on job embeddedness and performance outcomes. J. Bus. Econ. Manag. 2012, 13, 614-636. [CrossRef] 
41. Jiang, K.; Lepak, D.P.; Hu, J.; Baer, J.C. How does human resource management influence organizational outcomes? A meta-analytic investigation of mediating mechanisms. Acad. Manag. J. 2012, 55, 1264-1294. [CrossRef]

42. Sun, L.-Y.; Aryee, S.; Law, K.S. High-performance human resource practices, citizenship behavior, and organizational performance: A relational perspective. Acad. Manag. J. 2007, 50, 558-577. [CrossRef]

43. Tang, T.W.; Tang, Y.-Y. Promoting service-oriented organizational citizenship behaviors in hotels: The role of high-performance human resource practices and organizational social climates. Int. J. Hosp. Manag. 2012, 31, 885-895. [CrossRef]

44. Safavi, H.P.; Karatepe, O.M. High-performance work practices and hotel employee outcomes: The mediating role of career adaptability. Int. J. Contemp. Hosp. Manag. 2018, 30, 1112-1133. [CrossRef]

45. Jaiswal, D.; Tyagi, A. Effect of high performance work practices on service innovative behavior. Tour. Rev. 2020, 75, 382-401. [CrossRef]

46. Jabbour, C.J.C.; Jabbour, A.B.L.S. Green human resource management and green supply chain management: Linking two emerging agendas. J. Clean. Prod. 2016, 112, 1824-1833. [CrossRef]

47. Teixeira, A.A.; Jabbour, C.J.C.; Jabbour, A.B.L.S. Relationship between green human resource management and environmental training in companies located in Brazil: A theoretical framework and case studies. Int. J. Prod. Econ. 2012, 140, 318-329. [CrossRef]

48. Nili, A.; Tate, M.; Barros, A.; Johnstone, D. An approach for selecting and using a method of inter-coder reliability in information management research. Int. J. Inf. Manag. 2020, 54, 102154. [CrossRef]

49. Pérezts, M.; Picard, S. Compliance or comfort zone? The work of embedded ethics in performing regulation. J. Bus. Ethics 2015, 131, 833-852. [CrossRef]

50. Siano, A.; Vollero, A.; Conte, F.; Amabile, S. More than words: Expanding the taxonomy of greenwashing after the Volkswagen scandal. J. Bus. Res. 2017, 71, 27-37. [CrossRef]

51. Scheidler, S.; Edinger-Schons, L.M.; Spanjol, J.; Wieseke, J. Scrooge posing as Mother Teresa: How hypocritical social responsibility strategies hurt employees and firms. J. Bus. Ethics 2019, 157, 339-358. [CrossRef]

52. Miao, Q.; Zhou, J. Corporate hypocrisy and counterproductive work behavior: A moderated mediation model of organizational identification and perceived importance of CSR. Sustainability 2020, 12, 1847. [CrossRef]

53. Luu, T.T. Green human resource practices and organizational citizenship behavior for the environment: The roles of collective green crafting and environmentally specific servant leadership. J. Sustain. Tour. 2019, 27, 1167-1196. [CrossRef]

54. Gupta, V. Talent management dimensions and their relationship with retention of Generation -Y employees in the hospitality industry. Int. J. Contemp. Hosp. Manag. 2019, 31, 4150-4169. [CrossRef]

55. Kloutsiniotis, P.V.; Mihail, D.M. High performance work systems in the tourism and hospitality industry: A critical review. Int. J. Contemp. Hosp. Manag. 2020, 32, 2365-2395. [CrossRef]

56. Karatepe, O.M.; Vatankhah, S. The effects of high-performance work practices and job embeddedness on flight attendants' performance outcomes. J. Air Transp. Manag. 2014, 37, 27-35. [CrossRef]

57. Rodríguez-Sánchez, J.-L.; Montero-Navarro, A.; Gallego-Losado, R. The opportunity presented by technological innovation to attract valuable human resources. Sustainability 2019, 11, 5785. [CrossRef]

58. Jabbour, C.J.C.; Santos, F.C.A. Relationships between human resource dimensions and environmental management in companies: Proposal of a model. J. Clean. Prod. 2008, 16, 51-58. [CrossRef]

59. Zhao, J.; Liu, H.; Sun, W. How proactive environmental strategy facilitates environmental reputation: Roles of green human resource management and discretionary slack. Sustainability 2020, 12, 763. [CrossRef]

60. Ren, S.; Tang, G.; Jackson, S.E. Green human resource management research in emergence: A review and future directions. Asia Pac. J. Manag. 2018, 35, 769-803. [CrossRef]

61. Bombiak, E.; Marciniuk-Kluska, A. Green human resource management as a tool for the sustainable development of enterprises: Polish young company experience. Sustainability 2018, 10, 1739. [CrossRef]

62. Tuan, L.T. Driving employees to serve customers beyond their roles in the Vietnamese hospitality industry: The roles of paternalistic leadership and discretionary HR practices. Tour. Manag. 2018, 69, 132-144. [CrossRef]

63. Afsar, B.; Shahjehan, A.; Shah, S.I. Frontline employees' high-performance work practices, trust in supervisor, job embeddedness and in hospitality industry. Int. J. Contemp. Hosp. Manag. 2018, 30, 1436-1452. [CrossRef]

64. Ahmad, S. Green human resource management: Policies and practices. Cogent Bus. Manag. 2015, 2, 1-13. [CrossRef] 
65. Jia, J.; Liu, H.; Chin, T.; Hu, D. The continuous mediating effects of GHRM on employees' green passion via transformational leadership and green creativity. Sustainability 2018, 10, 3237. [CrossRef]

66. Bohdanowichz, P.; Zientara, P.; Novotna, E. International hotel chains and environmental protection: An analysis of Hilton's we care! Program (Europe, 2006-2008). J. Sustain. Tour. 2011, 19, 797-816. [CrossRef]

67. Wear an Even Greener Apron. Available online: https://www.starbucksglobalacademy.com/greener-apron (accessed on 13 August 2020).

68. Wyndham 2019 Social Responsibility Report. Available online: https://corporate.wyndhamhotels.com/wp-c ontent/uploads/2019/07/Wyndham-GRI-2019-Final_web.pdf (accessed on 13 August 2020).

69. Srivastava, A.P.; Shree, S. Examining the effect of employee green involvement on perception of corporate social responsibility: Moderating role of green training. Manag. Environ. Qual. Int. J. 2019, 30, 197-210. [CrossRef]

70. Pham, N.T.; Thanh, T.V.; Tučková, Z.; Thuy, V.T.N. The role of green human resource management in driving hotel's environmental performance: Interaction and mediation analysis. Int. J. Hosp. Manag. 2020, 88, 102392. [CrossRef]

71. Pham, N.T.; Tučková, Z.; Phan, Q.P.T. Greening human resource management and employee commitment towards the environment: An interaction model. J. Bus. Econ. Manag. 2019, 20, 446-465.

72. Forrester, R. Empowerment: Rejuvenating a potent idea. Acad. Manag. Exec. 2000, 14, 67-80. [CrossRef]

73. Tariq, S.; Jan, F.A.; Ahmad, M.S. Green employee empowerment: A systematic literature review or state-of-art in green human resource management. Qual. Quant. 2016, 50, 237-269. [CrossRef]

74. Tuan, L.T. Effects of environmentally-specific servant leadership on green performance via green climate and green crafting. Asia Pac. J. Manag. 2019. [CrossRef]

75. Kraimer, M.L.; Seibert, S.E.; Wayne, S.J.; Liden, R.C.; Bravo, J. Antecedents and outcomes of organizational support for development: The critical role of career opportunities. J. Appl. Psychol. 2011, 96, 485-500. [CrossRef]

76. Bauer, T.N.; Aiman-Smith, L. Green career choices: The influence of ecological stance on recruiting. J. Bus. Psychol. 1996, 10, 445-458. [CrossRef]

77. Chaudhary, R. Green human resource management and employee green behavior: An empirical analysis. Corp. Soc. Responsib. Environ. Manag. 2020, 27, 630-641. [CrossRef]

78. Coyle-Shapiro, J.A.M.; Morrow, P.C. The role of individual differences in employee adoption of TQM orientation. J. Vocat. Behav. 2003, 62, 320-340. [CrossRef]

79. Jabbour, C.J.C. How green are HRM practices, organizational culture, learning, and teamwork? A Brazilian study. Ind. Commer. Train. 2011, 43, 98-105. [CrossRef]

80. Brough, P.; Timms, C.; O’Driscoll, M.P.; Kalliath, T.; Siu, O.-L.; Sit, C.; Lo, D. Work-life balance: A longitudinal evaluation of a new measure across Australia and New Zealand workers. Int. J. Hum. Resour. Manag. 2014, 25, 2724-2744. [CrossRef]

81. Rodríguez-Sánchez, J.-L.; González-Torres, T.; Montero-Navarro, A.; Gallego-Losado, R. Investing time and resources for work-life balance: The effect on talent retention. Int. J. Environ. Res. Public Health 2020, 17, 1920. [CrossRef]

82. Muster, V.; Schrader, U. Green work-life balance: A new perspective for green HRM. Ger. J. Res. Hum. Resour. Manag. 2011, 25, 140-156. [CrossRef]

83. Jackson, J.E. Participation in decision making as a strategy for reducing job-related strain. J. Appl. Psychol. 1983, 68, 3-19. [CrossRef]

84. Boley, B.B.; Uysal, M. Competitive synergy through practicing triple bottom sustainability: Evidence from three hospitality case studies. Tour. Hosp. Res. 2013, 13, 226-238. [CrossRef]

85. Pinzoni, M.; Guerci, M.; Lettieri, E.; Huisingh, D. Effects of 'green' training on pro-environmental behaviors and job satisfaction: Evidence from the Italian healthcare sector. J. Clean. Prod. 2019, 226, 221-232. [CrossRef]

86. Harter, J. 4 Factors Driving Record-High Employee Engagement in the U.S. Available online: https: //www.gallup.com/workplace/284180/factors-driving-record-high-employee-engagement.aspx (accessed on 21 May 2020).

87. Schaufeli, W.B.; Salanova, M.; Gonzáles-Romá, V.; Bakker, A.B. The measurement of engagement and burnout: A two sample confirmatory factor analytic approach. J. Happiness Stud. 2002, 3, 71-92. [CrossRef]

88. NG, S.I.; Sambasivan, M.; Zubaidah, S. Antecedents and outcomes of flight attendants' job satisfaction. J. Air Transp. Manag. 2011, 17, 309-313. [CrossRef] 
89. Alarcon, G.M.; Lyons, J.B. The relationship of engagement and job satisfaction in working samples. J. Psychol. 2011, 145, 463-480. [CrossRef]

90. Zibarras, L.D.; Coan, P. HRM practices used to promote pro-environmental behavior: A UK survey. Int. J. Hum. Resour. Manag. 2015, 26, 2121-2142. [CrossRef]

91. Iranmmanesh, M.; Zailani, S.; Moeinzadeh, S.; Nikbin, D. Effect of green innovation on job satisfaction of electronic and electrical manufacturers' employees through job intensity: Personal innovativeness as moderator. Rev. Manag. Sci. 2017, 11, 299-313. [CrossRef]

92. Kim, S.-H.; Kim, M.; Han, H.-S.; Holland, S. The determinants of hospitality employees' pro-environmental behaviors: The moderating role of generational differences. Int. J. Hosp. Manag. 2016, 52, 56-67. [CrossRef]

93. Malik, S.Y.; Cao, Y.; Mughal, Y.H.; Kundi, G.M.; Mughal, M.H.; Ramayah, T. Pathways towards sustainability in organizations: Empirical evidence on the role of green human resource management practices and green intellectual capital. Sustainability 2020, 12, 3228. [CrossRef]

94. Chaudhary, R. Green human resource management and job pursuit intention: Examining the underlying process. Corp. Soc. Responsib. Environ. Manag. 2020, 26, 929-937. [CrossRef]

95. Kaya, B.; Karatepe, O.M. Does servant leadership better explain work engagement, career satisfaction, and adaptive performance than authentic leadership? Int. J. Contemp. Hosp. Manag. 2020, 32, 2075-2095. [CrossRef]

96. Karatepe, O.M.; Ozturk, A.; Kim, T.T. The effects of nonwork and personal resources on frontline bank employees' work engagement and critical job outcomes. Int. J. Bank Mark. 2019, 37, 858-879. [CrossRef]

97. Grobelna, A. Effects of individual and job characteristics on hotel contact employees' work engagement and their performance outcomes: A case study from Poland. Int. J. Contemp. Hosp. Manag. 2019, 31, 349-369. [CrossRef]

98. Koc, E.; Boz, H. Development of hospitality and tourism employees' emotional intelligence through developing their emotion recognition abilities. J. Hosp. Mark. Manag. 2020, 29, 121-138. [CrossRef]

99. Tambe, P.; Cappelli, P.; Yakubovich, V. Artificial intelligence in human resources management: Challenges and a path forward. Calif. Manag. Rev. 2019, 61, 15-42. [CrossRef]

100. Nili, A.; Barros, A.; Tate, M. The public sector can teach us a lot about digitizing customer service. Mit Sloan Manag. Rev. 2019, 60, 84-87.

(C) 2020 by the authors. Licensee MDPI, Basel, Switzerland. This article is an open access article distributed under the terms and conditions of the Creative Commons Attribution (CC BY) license (http://creativecommons.org/licenses/by/4.0/). 